\title{
Sino-America Trade Agreement: Legal Affairs and Translation
}

\author{
Guanghua Chen (Corresponding author) \\ School of Foreign Studies, Nantong University, China \\ Email:prccgh@gmail.com
}

Received: $21 / 01 / 2021$

Accepted: 05/04/2021

Published: 01/05/2021

Volume: 2 Issue: 3

How to cite this paper: Chen, G. (2021). Sino-America Trade Agreement: Legal Affairs and Translation. Journal of Critical Studies in Language and Literature, 2(3), 27-34

DOI: https://doi.org/10.46809/jcs1l.v2i3.67

Copyright ( 2020 by author(s) and Global Talent Academy Ltd. This work is licensed under the Creative Commons Attribution International License (CC BY 4.0).

http://creativecommons.org/licenses/by/4.0/

\section{(c) (9)}

\begin{abstract}
The Trade Agreement between China and the U.S., as any agreement does, imposes obligations or grant rights to the parties. As it is known by the public, the Chinese agreement versions are generated from translation of the English version instead of being independently negotiated, yet both versions are equally effective. The differences between the two legal systems, between the two languages, and even between the mentalities of the two peoples all play an important part in the execution of the agreement. Every word, complex or simple, is closely associated with obligations and rights, and negligence in translation is not acceptable. The present study aims to make some suggestions for the improvement of the Chinese version and call attention to the issues likely to be hidden at the back. Research in related areas is relatively scarce. This study, expounding from translation and legal perspectives, might contribute to clarifying the obligations and rights of the two contractual parties and the academic circle. And it tentatively proposes the new term of paradigm equivalence.
\end{abstract}

Keywords: US-China Trade Agreement, Continental Law System, Anglo-American Law System, Contract Translation, Faithfulness, Translation Strategies, Paradigm Equivalence

\section{Introduction}

China and US, the two great economic powers, reached a trade agreement on January 15, 2020 just before Covid-19 started to rage around the world. This, as a demonstration of force majeure, makes it impossible for the agreement to be fulfilled. The agreement, designed to promote economic and cultural communication between the two countries, is now de facto discarded due to various reasons. However, any leakage with the texts (Chinese and English) might render them not so practical. This calls attention from the translation studies community. Furthermore, the question is raised whether the two parties can find any good reason to shy away from their contractual obligations without being punished just because of the different connotations or explanations of the terms and expressions? A translator's perspective with some help of a comparative study of the legal systems in the two countries will provide some insight different from what the economic community cares about since a translation in this field requires not just translation skills and proficiency in both languages, but also some preparation in the legal systems of both countries.

There are considerable differences in the law systems of the two countries, in the two languages, and in the legal mentalities of the public. All this will have some impact on how one language is translated into another. Laws themselves make "a web of norms that includes strictly legal but also moral, ethical and conventional norms" (Hasegawa, 2015, P. 504), which makes activities in the area complicated, requiring meticulous care. Furthermore, translation itself, directed by multiple theories, is quite an elusive matter. When such factors work together, the claimed authenticity of the translated text becomes doubtable. A translator's perspective with considerations of legal traditions might provide some different insights. With an 
analysis of the examples out of which misinterpretations might emerge, this study hopes to make some clarifications in regard to the translation of the agreement in particular, and to call attention to legal translation in general.

As the basis for the following discussion, all the quotations from the agreements have been exclusively collected from the files on the official site of Ministry of Commerce of People's Republic of China.

\section{Major differences in the legal systems of China and US}

Mainland China adopts the continent legal system, while the U.S. adopts the Anglo-American common law system. Differences in the two legal systems, as has been pointed out in "Contrast Between Common and Continental Legal Systems," are remarkable: "The common law legal system perceives law as a tool only to limit state government, whereas according to the continental legal system, it restricts but also empowers state government." Government authorities of the common legal system are concerned with what they cannot do, while the other side is thinking about what they can "rightfully" do by any legal documents, and, thus; they are fond of making new laws.

Table 1. Overview of the major difference in the two legal systems ${ }^{1}$

\begin{tabular}{|l|l|l|}
\hline & Continental law system & Common law system \\
\hline Source of law & $\begin{array}{l}\text { Legislation } \\
\text { Legal codes } \\
\text { The rule of continental law is to } \\
\text { build a bridge of available and } \\
\text { written collection of the laws which } \\
\text { concern all citizens and which } \\
\text { judges must follow. }\end{array}$ & $\begin{array}{l}\text { Previous judicial verdicts, with statutes } \\
\text { working as supplements to judicial } \\
\text { opinions. }\end{array}$ \\
\hline $\begin{array}{l}\text { Judges' } \\
\text { authorities }\end{array}$ & $\begin{array}{l}\text { "Investigators, basing their verdicts } \\
\text { on law and on documentary proof, } \\
\text { greater flexibility, } \\
\text { Likely to be superseded by other } \\
\text { authorities }\end{array}$ & $\begin{array}{l}\text { Following precedents, or in the absence } \\
\text { of these, fashioning new rules (making } \\
\text { law) from logic of related rules or } \\
\text { underlying principles } \\
\text { Mandatory in similar cases }\end{array}$ \\
\hline $\begin{array}{l}\text { Administrative } \\
\text { justice }\end{array}$ & $\begin{array}{l}\text { Autonomy of judicial jurisdiction } \\
\text { arbitrator); courts, independent }\end{array}$ & $\begin{array}{l}\text { Administrative tribunals (quasi-judicial } \\
\text { authorities) who are actively involved in } \\
\text { gathering evidence and investigation; }\end{array}$ \\
\hline Lawyer's role & $\begin{array}{l}\text { Somewhat diminished in court } \\
\text { Quasi-legal professionals allowed to } \\
\text { play a role in some legal areas }\end{array}$ & $\begin{array}{l}\text { Active in court } \\
\text { Dominating the preparation of any legal } \\
\text { document, conducting their own pre-trial } \\
\text { investigations }\end{array}$ \\
\hline
\end{tabular}

Table 1 displays a list of the major differences, not necessarily exhaustive, yet each might play a significant role in deciding how the agreement can be carried out. Although the two versions of the agreement are "equally authentic" (Article 8.6), each side can have their own interpretation based on their own firm standpoint at their own convenience. Moreover, given that legal matters concerning agreements are so delicate, it would considerably comprise the feasibility.

Some may argue that the two cannot be clearly demarcated, each being somewhat a hybrid. That surely makes sense, but it does not matter much for our discussion here because what we consider is the mentality nurtured out of the long history of a certain legal environment. The great gap is not likely to be easily bridged, and it is likely to play a considerable role in the fulfillment of the agreement. In case of conflicts, it is important to observe whose opinions get voiced. Each version is sure to hold the expression in its own interest.

\section{Major Differences in the Two Languages Directly Related to the Fulfillment of the Agreement}

Since both versions are equally authentic, how the intentions or meanings are expressed has to be attended to. The two languages are sharply different from each other: Firstly, English, a highly lexicalized language with rich resources of derivatives, compounds, conversions, loans, and acronyms, is abundant with synthetic expressions. In contrast to this, Chinese language relies heavily on simpler expressions and phrases, run-on subordinates prevalent and highly acceptable. In this regard, "legal translation is not only considered as a language transformation process, but also as a communicative activity in the legal mechanism, aiming at the realization of legal functional equivalence" (Zhang 2020, p. 51). However, lexical variations in English prove to be very difficult for translators to find "equivalents" in Chinese. Secondly, for English sentences, grammar plays a very significant role, without which no effective communication can be made. This is different in Chinese language in which the meaning is likely to be hidden behind the characters and phrases, and the contextual relationship comes out of the understanding of readers or listeners, and in which interpretation is highly varied. Thirdly, meanings conveyed by modal verbs can be quite confusing and elusive in Chinese (some may argue that such modal verbs do 
not exist in Chinese), as their precise equivalents in English not easily found; however, sometimes they are presented in the form of adjectives or adverbs (Hung \& Pollard 1998, p. 165). Thus, the meaning might be changed considerably. Fourthly, in regard to the commonly used sentence patterns such as the passive voice and the subjunctive mood, there is also something subtle likely to interfere with the interpretation of the texts. Eugene Nida argues for "dynamic equivalence," favoring the correspondence between senses, focusing on the readability and reader responses of the target text. He later develops this into "functional equivalence" with more focus on cultural factors. ${ }^{2}$ However seemingly reasonable and fitting, his arguments are severely criticized by Lawrence Venuti for being ethnocentric, hegemonic, racist, culturally narcissistic and imperialistic (1995, p. 20). However contradictory they are with each other, their arguments provoke some thoughts for translators in the search for "equivalents." In this regard, the followings are some examples from the agreement:

1. Meaning becomes more elusive in Chinese, certainty dangling in the air, but what might be overlooked at a glance could be of vital importance for a professional. For example:

$\ldots$ the Parties shall engage in expedited consultations on the response to the damages or losses incurred by the

Complaining Party (Article 7.4-4, emphasis mine, similar hereinafter).

The proposition "by" in this clause makes it very confusing: we are not sure whether it is "response by the Complaining Party" or it is "damages or losses (which are) incurred by the Complaining Party". The translator interferes with this confusion and makes a voluntary correction (or rather, choice of meaning) by putting it to “双方应就申诉方所受损害或损 失的回应快速进行硣商." But the two versions do not correspond with each other. The original is so vague, and the translated text is so clearly stated.

2. As a common feature of human language, polysemy is not uncommon. For those substantive words or expressions, we are armed with reasonable interpretation measures to weigh the interests of both sides. Problems with "small words" that are likely to cause unresolvable divergence might have been neglected in the translation texts. For example:

Original text: If the Parties do not reach consensus on a response, the Complaining Party may resort to taking action based on facts provided during the consultations, including by suspending an obligation under this Agreement or by adopting a remedial measure in a proportionate way that it considers appropriate with the purpose of preventing the escalation of the situation and maintaining the normal bilateral trade relationship (Article 7.4-4).

Chinese equivalence: 如果双方未就上述回应达成共识，申诉方出于防止局势升级、维护正常双边贸易关 系的目的，基于硡商中提供的事实，可能求助于采取行动，包括停止其在本协议下的某一义务，或采 取其认为适当的、以相称的方式实施的补救措施。

In the English text, "may", according to the context, grants the related party the "privilege" of taking actions, but in the Chinese text, “可能” indicates a possibility, which sounds quite like a warning. Similarly, the article "an" in the English text makes its appearance for grammatical reasons and does not limit the measure to be taken by the party to just "one", but the Chinese equivalent “某一” could be a limitation when it appears here in this serious and formal document. Therefore, the following would be a better version:

如果双方未就上述回应达成共识，申诉方出于防止局势升级、维护正常双边贸易关系的目的，基于硣 商中提供的事实, 可以采取行动，包括停止其在本协议下的义务，或采取其认为适当的、以相称的方 式实施的补救措施。

3. The widely applied principle of "faithfulness" in translation, when taken to the extreme, might lead to misinterpretations. In fact, there is no consensus in regard to what "faithfulness" means within the circle of translators (for example, to whom should a translator be faithful, the original, or the target, or even the market?). Moreover, rigid observers might be caught in the difficulty of finding appropriate expressions in the target language if they fail to deal with the original text as an organic whole. Dictionaries are indispensable for translators, but they must be aware of the fact that bilingual equivalents in dictionaries are often separated from contexts, and, thus; this could be misleading. The "otherwise" in the following could serve as a great example:

If the Party Complained Against considers that the action by the Complaining Party pursuant to this subparagraph was taken in good faith, the Party Complained Against may not adopt a counter-response, or otherwise challenge such action (Article 7.4-4).

Chinese equivalence: 如被申诉方认为申诉方依照本项采取的行动基于善意，被申诉方不会采取反制措施 , 或否则挑战相关行动。

"Otherwise" is explained as "in a different way" or as "an alternative", but the Chinese equivalent, tinged with a sense of negation, sounds quite strange. It would sound much more natural if we say, “如被申诉方认为申诉方依照本项采取的行动 基于善意, 被申诉方不可采取反制措施, 也不可对申诉方行动采取针对性行动." The issue with “may" has already been mentioned in the previous example.

4. In rare instances, substantive words pose some troubles in case of legal texts, and differences in languages might lead to confusion. The "Parties" here attracts our attention:

In the event that a natural disaster or other unforeseeable event outside the control of the Parties delays a Party from timely complying with its obligations under this Agreement, the Parties shall consult with each other (Article 7.6). 
Chinese equivalence: 如因自然灾害或其他双方不可控的不可预料情况, 导致一方延误, 无法及时履行本

协议的义务，双方应进行磋商。

This article is obviously a requirement on the obligator in case of "force majeure": its occurrence is supposedly to exempt the party from certain obligations, to the disadvantage of the other party, and thus a consultation is needed. Therefore, as long as the event is outside the control of the obliged party, the precondition is met. The Chinese equivalent of "Parties", that is " 双方” provides room for argument. In this regard, when one party does not take it as "force majeure", the other party would be inevitably thrown into a disadvantageous position. Additionally, the meaning of a "natural disaster" or "other unforeseeable event" is vague. However, for such instances of "force majeure," there is a clear definition (explanation) in their Chinese equivalence, “不可抗力," which dodges the entanglement of the "Parties" (NPC, 2002). Enlightened by that explanation, “当事方” would be a very appropriate replacement for “双方.” Similar examples can be found as follows:

1. The Parties shall ensure fair, adequate, and effective protection and enforcement of intellectual property rights. Each Party shall ensure fair and equitable market access to persons of the other Party that rely upon intellectual property protection (Article 1.2).

2. China shall... substantially lower all the thresholds for initiating criminal enforcement (Article 1.7).

3. And in the repeated phrase of "except in exceptional circumstances".

The voluminous use of general and abstract modifiers like "fair, adequate, effective, substantially, exceptional, etc." low in enforceability points directly to the conscience, contract spirit, and legal awareness.

\section{Directly Translation-Related Issues}

Just as the situation in any other professional sphere, translation is directed by multiple notions, concepts, and theories emerging in an endless succession. Any translation could invite appraisal and criticism. We try whatever possible to occupy a "neutral" (though impossible) position mediating between them.

In the translation of the "Agreement", the dilemma of making a choice between "foreignization" and "domestication" starts to materialize. The techniques that are used in the translation of the Agreement aim to make the target text readable and intelligible as well as practicable. Furthermore, legal language is characterized by its preciseness and conciseness apart from all the terms and jargons. This must necessarily be a particular requirement for translation in this field. Kennedy (2000) argues,

"Legalese" can be viewed as a different language altogether. In this "foreign" language, words and phrases are either open to interpretation, or they have meanings that result from decades of case law and theory, for example, "due process," "duty of care," and "consideration." Thus a non-lawyer cannot translate English legalese into non-legal, "normal" English language. Furthermore, a non-lawyer translator would translate the English legal language into an incomprehensible or vague target language phrase. (P.3)

Thus, particular attention must be paid to legal features of both the source and the target texts. For example:

1. Original text: Each Party shall ensure fair and equitable market access to persons of the other Party that rely upon intellectual property protection (Article 1.2).

Its Chinese equivalence: 对于依赖知识产权保护的一方个人, 对方应确保为其提供公平、平等的市场准 入。

Original text: Natural or legal persons ("persons") of a Party shall have effective access to and be able to operate openly and freely in the jurisdiction of the other Party without any force or pressure from the other Party to transfer their technology to persons of the other Party (Article 2.1).

Its Chinese equivalence: 一方的自然人或法人 (“个人”) 应能够有效进入对方管辖区，公开、自由地开展 运营，而不会受到对方强迫或压力向其个人转让技术。

The first point worth mentioning here is “对于依赖知识产权保护的一方.” The expression sounds somewhat strange for those familiar with Chinese legal files as for them “对于受知识产权保护的一方” might be more natural.

Then, the "persons" is translated as “个人” in the first example, “个人” includes both "natural and legal persons." This is confusing and even misleading as in Chinese"个人” refers to "natural persons" only; the inclusion of "legal persons" into it would go well beyond the expectations of the public as well as legal professionals. However, in English this is not a problem as “persons" can serve as the hypernym of both. Thus, it would be better to put the first “persons" into “自然人或法人” and omit the "persons" in brackets (respective changes to be made in the following texts). So the equivalences g could be as follows:

对于受知识产权保护的一方自然人或法人，对方应确保提供公平、平等的市场准入； and

一方自然人或法人应能够实际进入对方管辖区, 公开、自由地开展运营, 而不会受到强迫或压力向其 自然人或法人转让技术。

2. Original text: China shall define "operators" in trade secret misappropriation to include all natural persons, groups of persons, and legal persons (Article 1.3).

Its Chinese equivalence: 中国应将侵犯商业秘密的“经营者”定义为包括所有自然人、组织和法人.

Original text: holder of a trade secret (Article 1.7) 
Its Chinese equivalence: 商业秘密权利人

In these two examples, an operator should necessarily include actual business operators (经营者), but there are other infringers not to be excluded. Thus, “行为人” might be a better equivalent. "Holder" of a trade secret refers to the individual who is actually in possession of that secret; but the Chinese equivalent, “权利人”, including the licenses of any form, has a much wider coverage while the "holder" is authorized to initiate legal actions here. It, therefore, should be “商业秘密持有人

3. Original text: ...breach or inducement of a breach of duty not to disclose information that is secret or intended to be kept secret (Article 1.4).

Its Chinese equivalence: 违反或诱导违反不披露秘密信息或意图保密的信息的义务.

The Chinese expression of “意图保密” sounds awkward and difficult to understand. The "intention” in the "intended” is designed into the clause, and thus both sides should be aware of their own obligations. Therefore, it would be better to say " 违反或诱导违反不披露保密或应当保密信息的义务”.

4. Original text:...under the circumstance that the right holder provides preliminary evidence that measures were taken to keep the claimed trade secret confidential, the burden of proof or burden of production of evidence, as appropriate, shifts to the accused party to show that a trade secret identified by a holder is generally known among persons within the circles that normally deal with the kind of information in question or is readily accessible, and therefore is not a trade secret (Article 1.5-2).

Its Chinese equivalence: 在权利人提供初步证据, 证明其已对其主张的商业秘密采取保密措施的情形下, 举证责 任或提供证据的责任（在各自法律体系下使用适当的用词）转移至被告方, 以证明权利人确认的商业秘密为通常处 理所涉信息范围内的人所普遍知道或容易获得, 因而不是商业秘密。

"Burden of proof" is a legal duty that encompasses two connected but separate ideas for establishing the truth in a trial before tribunals in the United States: the "burden of production" and the "burden of persuasion." "Burden of production of evidence" means to provide certain evidence, literally. The two are different obligations, and are to be applied according to different cases. Therefore, a better version would be:

若权利人提供初步证据证明其已对所主张的商业秘密采取保密措施，视案情而定,证明责任或举证责任 转移至被告方, 以证明权利人确认的商业秘密通常为相关行业领域人士所知晓或易于取得, 因而不构 成商业秘密。

Similarly,

Original text: In civil, administrative, and criminal proceedings involving copyright or related rights, the Parties shall provide that the accused infringer has the burden of production of evidence or burden of proof, as appropriate, to demonstrate that its use of a work protected by copyright or related rights is authorized, including in a case where the accused infringer claims to have obtained permission to use the work, such as through a license, from the right holder (Article 1.29).

Its Chinese equivalence: 在涉及著作权或相关权的民事、行政和刑事程序中，双方应规定被诉侵权人承 担提供证据的责任或举证责任（在各自法律体系下使用适当的用词），证明其对受著作权或相关权保 护的作品的使用是经过授权的，包括被诉侵权人声称已经从权利人获得使用作品的准许的情况，例如 许可。

Here commonly accepted translation for "copyright or related rights" exists. It makes no sense to puzzle the legal professionals with a different expression, so it should be:

在涉及著作权或邻接权的民事、行政和刑事程序中, 视案情而定, 双方应规定被诉侵权人承担举证或 证明责任证明其受授权使用受著作权或相关权利保护的作品, 包括被诉侵权人主张已经从权利人获得 授权使用作品的情况，例如许可。

5. Original text: The Parties shall provide for prompt and effective provisional measures to prevent the use of misappropriated trade secrets (Article 1.6).

Its Chinese equivalence: 双方应规定及时、有效的临时措施，以阻止使用被侵犯的商业秘密。

"Misappropriated trade secrets" should not limit the right(s) of holders of such secrets; infringers who have misappropriated such secrets should be restricted. It would be better to say “双方应及时采取有效的临时措施, 以阻止使 用窃取的商业秘密”。

6. Original text: China shall identify the use or attempted use of claimed trade secret information as an "urgent situation" that provides its judicial authorities the authority to order the grant of a preliminary injunction based on the specific facts and circumstances of a case (Article 1.6).

Its Chinese equivalence: 中国应将使用或试图使用所主张的商业秘密信息认定为“紧急情况”, 使得司法机 关有权基于案件的特定事实和情形采取行为保全措施。

For the same reason as in (4), it would be better to say:

中国应将使用或试图使用被主张为商业秘密的行为认定为“紧急事项”, 使司法机关有权基于案件的特定 事实和情形签发诉前禁令。

7. Original text: China shall extend to 20 working days the deadline for right holders to file a judicial or administrative complaint after receipt of a counter-notification (Article 1.13). 
Its Chinese equivalence: 中国应将权利人收到反通知后提出司法或行政投诉的期限延长至 20 个工作日

A counter notification, under the Digital Millennium Copyright Act ("DMCA"), is a legal means to state your objection to a DMCA/copyright warning that you've received regarding a report of allegedly infringing copyrighted material on your account on social media such as YouTube. ${ }^{32}$

It should be put as “中国应将权利人收到抗辩书后提出司法或行政投诉的期限延长至 20 个工作日”. We have also found the following examples which require modification:

8. Original text: ...unauthorized disclosure or use that occurs after the acquisition of a trade secret under circumstances giving rise to a duty to protect the trade secret from disclosure or to limit the use of the trade secret (Article 1.4).

Original Chinese equivalence: 对于在有义务保护商业秘密不被披露或有义务限制使用商业秘密的情形下 获得的商业秘密，未经授权予以披露或使用。

Improved version: 对所取得的商业秘密在有义务不予披露或限制使用的情形下未经授权的披露或使用。

9. Original text: ...evidence that a trade secret has been or risks being disclosed or used by the accused party (Article 1.5).

Original Chinese equivalence: 商业秘密已被或存在遭被告方披露或使用的风险的证据。

Improved version: 商业秘密已为被告方披露或使用, 或存在该风险的证据。

10. Original text: China shall: as an interim step, clarify that "great loss" as a threshold for criminal enforcement under the trade secret provision in the relevant law can be fully shown by remedial costs, such as those incurred to mitigate damage to business operations or planning or to re-secure computer or other systems, and substantially lower all the thresholds for initiating criminal enforcement (Article 1.7).

Original Chinese equivalence: 中国：作为过渡措施，应澄清在相关法律的商业秘密条款中，作为刑事执 法门槛的“重大损失”可以由补救成本充分证明，例如为减轻对商业运营或计划的损害或重新保障计算机 或其他系统安全所产生的成本，并显著降低启动刑事执法的所有门监。

Improved version: 中国：作为过渡措施，应在涉及商业秘密的相关法律条款中明确作为刑事执法门槛的 “重大损失”可以由补救成本充分证明，例如为减轻商业经营、商业计划遭受的损害产生的支出，为重新 保障计算机或其他系统安全产生的支出，并显著降低启动刑事执法程序的所有门槛。

11. Original text: China shall require administrative agencies and other authorities at all levels to provide criminal, civil, and administrative penalties, including monetary fines, the suspension or termination of employment, and, as part of the final measures amending the relevant laws, imprisonment, for the unauthorized disclosure of a trade secret or confidential business information that shall deter such unauthorized disclosure (Article 1.9).

Original Chinese equivalence: 中国应要求各级行政机构和其他机构 对未经授权披露商业秘密或保密商务 信息的行为实施应阻遏此类未经授权披露的刑事、民事和行政处罚, 包括罚金和停止或终止聘用, 以 及作为修订相关法律的最终措施一部分的监禁。

Improved version: 中国应要求各级行政机构和其他机构对未经授权披露商业秘密或保密商务信息的行为 实施刑事、民事、行政处罚措施, 包括罚金, 暂停或终止聘用关系, 监禁（作为最终措施修改法律的 一部分），以遏止此类未经授权的披露行为。

12. Original text: China shall ensure validity of takedown notices and counter-notifications, by requiring relevant information for notices and counter-notifications and penalizing notices and counter-notifications submitted in bad faith (Article 1.13).

Original Chinese equivalence: 中国应通过要求通知和反通知提交相关信息，以及对恶意提交通知和反通 知进行处罚, 以确保下架通知和反通知的有效性。

Improved version: 中国应取得下架通知书、抗辩书提交者的相关信息，惩罚恶意提交通知书、抗辩书的 行为, 以保证通知书、抗辩书的有效性。

13. Original text: ...the Parties shall provide for effective protection and enforcement of pharmaceutical-related intellectual property rights, including patents and undisclosed test or other data submitted as a condition of marketing approval (Section C).

Original Chinese equivalence: 双方应为药品相关知识产权, 包括专利以及为满足上市审批条件而提交的 未经披露的试验数据或其他数据, 提供有效保护和执法。

Improved version: 双方应为药品相关知识产权提供有效保护，包括专利以及为满足上市审批条件而提交 的未经披露的试验数据或其他数据, 并提供有效执法。

14. Original text: China shall as a subsequent step, increase the range of minimum and maximum preestablished damages, sentences of imprisonment, and monetary fines to deter future intellectual property theft or infringements (Article 1.27).

Original Chinese equivalence: 中国, 作为后续措施, 应提高法定赔偿金、监禁刑和罚金的最低和最高限 度, 以阻遏未来窃取或侵犯知识产权的行为。 
Improved version: 中国, 作为后续措施, 应提高损害赔偿金、监禁期限、罚金的最低和最高标准, 以阻 遏未来窃取或侵犯知识产权的行为。

15. Original text: The United States affirms that existing U.S. measures afford treatment equivalent to that provided for in this Article (This is repeated severally in different places).

Original Chinese equivalence: 美国确认，美国现行措施给予与本条款规定内容同等的待遇。

Improved version: 美国确认，美国现行措施给予中国与本条款规定内容同等的待遇。

16. Original text: China shall ensure that the new standard and all implementing actions are consistent with China's WTO obligations (Annex 2).

Original Chinese equivalence: 中国应确保新标准及所有实施行动符合中国世界贸易组织义务。

Improved version: 中国应确保新标准及所有实施行动符合中国对世界贸易组织的承诺。

17. Original text: China shall normally complete within 40 working days of completing the technical review, provided the U.S. manufacturer provides timely access if needed, any audit, inspection, sampling, or testing that is required in order to register an infant formula product (Annex 2).

Original Chinese equivalence: 中国应: 通常在完成技术审查后 40 个工作日内, 完成贞幼儿配方乳粉产品 注册所需要的有关核查、检查、抽样或检测, 其条件是, 美国生产商在必要的情况下及时提供准入。 Improved version: 中国应: 只要美国生产商在必要时及时提供条件, 通常在完成技术审查后 40 个工作 日内, 完成贞幼儿配方乳粉产品注册所需要的有关审计、检查、抽样或检测。

18. Original text: Such auditing shall be risk-based (Annex 2).

Original Chinese equivalence: 核查应以风险为基础。

Improved version: 此类审计以风险的存在为前提。

19. Original text: The Parties shall not implement food safety regulations, or require actions of the other Party's regulatory authorities, that are not science-or risk-based and shall only apply such regulations and require such actions to the extent necessary to protect human life or health (Annex 17).

Original Chinese equivalence: 双方不得实施未基于科学和风险的食品安全法规或要求另一方监管部门未 基于科学和风险的行动，且应只使用该法规和要求该行动以保护人类生命或健康所需程度为限。

Improved version: 若不存在科学依据, 不存在风险, 双方不得实施食品安全法规, 或要求对方监管部门 采取行动，且实施食品安全法规、要求对方采取的监管行动仅以保护人类生命健康为限。

Strict adherence to the original may be promoted by some theories, but legal translation proves itself to be very particular. As Sarcevic (1997) has argued, "legal translation is essentially a process of translating legal systems. [...] if legal translation is to be effective, the so-called search for equivalents cannot be reduced to a process of matching up "equivalents"' (p.13). When legal texts are treated in this way, part of the translator's attention would be shifted to the context, and considerations to the above details would be sufficient enough.

\section{Conclusion}

Many factors play significant roles in the process of translation. Despite all the sensational influences theories impose, their observations can find little room to fit in legal translation where a "paradigm-for-paradigm" translation strategy or "paradigm equivalence" is required. Thus, the translator would find it necessary to probe into the legal area of the two entities and familiarize himself /herself with the legal environment and even cultural norms. Translation is a process in which we keep the pursuit of "equivalence," but in regard to legal translation, "equivalence" is only to be found in laws and regulations of the target instead of literal dictionaries or experience. In legal translation, the habits and customs of the target language are maintained. Each professional area has its own language, terms and habits which have to be observed in particular. Matters relating to agreements, law, economy might be directly associated with rights and obligations of corresponding parties, and thus should be handled with meticulous care.

\section{References}

"Burden of proof (law)." [Online] Available: https://en.wikipedia.org/wiki/Burden_of_proof_(law) (Consulted March 9, 2021)

"Contrast Between Common and Continental Legal Systems" [Online] Available: https://www.lawteacher.net/free-lawessays/constitutional-law/contrast-between-common-and-continental-legal-systems-constitutional-law-essay.php (Consulted March 8, 2021)

Hasegawa, K. (2015). "Normative translation in the heterogeneity of law." Transnational Legal Theory, 6(3-4), 501-517.

Hung, E. \& Pollard, D. (2001). "Chinese tradition." M. Baker (Ed.) (2001), Routledge Encyclopedia of Translation Studies (pp. 365-375). London: Taylor \& Francise.

Kennedy, R. (2000). "Much Ado about Noting: Problems in the Legal Translation Industry." Temple International and Comparative Law Journal, 14(2), 423-44.

Sarcevic, S. (1997). New Approach to Legal Translation. Alphen aan den Rijn: Kluwer Law International. 
Venuti, L. (1995). The Translator's Invisibility: a History of Translation. London: Routledge.

Zhang, F. (2020). "The Exploration of Anglo-American Legal Terminology Translation Strategies." International Forum of Teaching and Studies, 16(1), 51-57.

“因不可抗力不履行合同的，是否承担责任？” [Online] Available: http://www.npc.gov.cn/npc/c2400/200204/febf075efe3345498db5655f312d9727.shtml (Consulted March 8, 2021)

\section{Notes}

${ }^{1}$ 1. Information collected from:

1) https://www.lawteacher.net/free-law-essays/constitutional-law/contrast-between-common-andcontinental-legal-systems-constitutional-law-essay.php

2) https://www.encyclopedia.com/politics/encyclopedias-almanacs-transcripts-and-maps/common-lawanglo-american

3) https://onlinelaw.wustl.edu/blog/common-law-vs-civil-law/

4) https://iqdecision.com/en/the-continental-and-common-law-judicial-systems/

${ }^{2}$ References to be found at:

1) https://support.google.com/youtube/answer/2807684?hl=en https://www.verizonmedia.com/policies/us/en/verizonmedia/ip/counter-notification/index.html

2) https://www.verizonmedia.com/policies/us/en/verizonmedia/ip/counter-notification/index.html 